\title{
Fear and Hope in Angela Carter's Fictions.
}

\author{
Proshanta Sarkar \\ Department of English, Research Scholar, The University of Burdwan, West Bengal, India
}

\begin{abstract}
In Angela Carter's fictions are found three types of characters. In her earlier works we can find the female characters who are submissive and remain as 'puppet' controlled by the puppet player - the male gender. They have no free thought and wait for the society say the male gender to teach them what to do. But in her later works the female characters are quite impressive. They are self-determined and enjoy their natural sexuality and erotic desires. They are called the "New Women" - who think with their feminist views. Third types of women are those who transform themselves from the first type to the second. Carter here wants the readers to see the problems and 'fear' that the women encounter in the society, and through her "New Women", gives the message of 'hope' of how the women should see themselves.
\end{abstract}

Keywords: Carnivalesque, Determinism, Feminism, Post-Structuralism, Queer Theory

Classical Gothic fictions, like Mary Shelley's 'Frankenstein' (1818), Ann Radcliffe's 'Romance of the Forest' (1791), 'A Sicilian Romance' (1790), 'The Mysteries of Udolpho' (1794), Jane Austen's 'Northanger Abbey' (1817) and so on through their gothic modes announce the voice of feminity in the society which is controlled by the Enlightenment values of the patriarchal society. Dissatisfied by the procedure of the male dominated society where there is no free space for the women, the women writers collectively, through the gothic modes, protest against the society which thereby resonate with the song of feminity and try to subvert the gender hierarchy and ultimately come to the centre of critical discussion. But mostly, unconsciously entrapped by the male dominated values, they hardly portray their protests. Angela Carter is one such postmodern feminist writer who through the gothic mode successfully draws her desired and decisive thought. Through the portraiture of the 'entrapment' type of women, she catches our critical attention to the problems attached to the female gender. And further with her "New Woman' - one who is self-determined and self-controlled, Carter teaches the way a woman should think and do for herself. Now let us come to the female characters of Carter's fictions. Whenever the readers are going to explore the women characters in Angela Carter's fictions, they are shocked and surprised. Some women characters stir 'pity', some 'hope'. They open the readers' eyes to the problems they never think before. They provoke 'sympathy'. They show the glimpse of 'hope'. Actually, we cannot remain untouched by the presentation of the female characters in Carter's fictions.

So, let us take two of her most influential novels, 'The Magic Toyshop' (1967) and 'Nights at the Circus' (1984), and two of her collections of short stories, 'Fireworks' (1974) and 'The Bloody Chamber' (1979). As Carter's depiction of feminity is multifaceted, it will be useful if we categorise Carter's women characters into two main types - one stands for 'sympathy', and the other for 'hope'. And lastly we will discuss on the third type of feminity that is the transformation from the first type to the second.

In Paulina Palmer's essay 'Gender as Performance in the Fiction of Angela Carter and Margaret Atwood', binary division of women character is depicted. One is 'feminity as entrapment' which arises 'sympathy' in the readers, and the other is 'feminity as self-invention and role mobilization' which paves the way to the 'hope' (for the feminist). Carter's trajectory as a writer scales a shift from the former to the later which is exemplified by the shift of feminity from her early works to the later works - 'entrapment' type to 'self-invention type'.

While expressing about the first type of feminity, Paulina Palmer says, Carter "represents women as a puppet, performing scripts assigned to her by a male-supremacist culture". In this context Paulina Palmer uses the puppet metaphor to describe the first type of feminity. And it is quite understandable the first type of feminity through this fitted metaphor. A puppet clears out the sense of 'passivity'. It is controlled by the puppet player. Such is the characteristic of 'entrapment' type feminity [1]. The character "Sleeping Beauty" is a strong personification of this type of feminity from 'Nights at the Circus':

'Oh, what a tragic case, sir! She was a country curate's daughter and bright and merry as a grig, until, one morning in her fourteenth year, the very day her menses 
started, she never wakened, not until noon; and the day after, not until teatime; and the day after that, her grieving parents watching and praying beside her bed, she opened her eyes at supper-time and said: "I think I could fancy a little bowl of bread and milk.", [2]

Every night, the naked "Sleeping Beauty" becomes the part of a sensual exhibition of Madame Schreck's Women Monster. The girl at that time develops as a sexual object in the minds of the lustful men. She is raped by the hungry staring of the men at the exhibition. The girl falls into the state of ongoing sleep when she becomes woman that is when her menstruation starts. Thus she can be seen as an embodiment of passivity as state of sleeping is unmistakably a metaphor of passivity. In a roundabout way, Carter focuses on the concept that being female sometimes is being passive. Thus 'Nights at the Circus' can be regarded as prototypical for its representation of 'entrapment' type feminity.

Another novel, 'The Magic Toyshop' also highlights the concept of 'entrapment' type feminity through the representations of Melanie, a fifteen years old girl and her aunt Margaret. They are considered puppets the strings of which are controlled by the omnipotent male protagonist, Melanie's uncle Philip. Dominated by the cruel actions and decisions of Philip, they cannot freely express their wills and live in fear. Melanie's fear becomes clear in the following passage:

"She saw her uncle only at meal times but his presence, brooding and oppressive, filled the house. She walked warily as if his colourless eyes were judging and assessing her all the time." [3]

Melanie has to play the female protagonist in the puppet performance of the "Leda and the Swan" held by Philip. There during a rape scene Melanie is literary transformed into a doll that is assaulted sexually by Philip. Here he crosses the boundary, and apart from the puppet-control, he controls Melanie sexually in his imagination:

“... she could see Uncle Philip directing its movements.

His mouth gaped open with concentration. [...] Uncle Philip's voice, deep and solemn as the notes of an organ, moved dark and sonorous against the moaning of the fiddle. The swan made a lumpish jump forward and settled on her loins. She thrust with all her like a tent and its head fell forward and nestled in her neck. [...] She was covered completely by the swan but for her kicking feet and her screaming face. " [4]

Here Philip dominates Melanie sexually in an indirect way and considers her as a puppet. Melanie is shocked during the rape scene and feels herself not herself. She watches the whole fantasy from another place. She feels as if Leda is not raped but herself definitely is. Here she loses her identity, her empowerment.

Aunt Margaret also feels the same fear in presence of Philip. She is in a way dogged by her husband. She is here more submissive than Melanie. The chocking necklace is the metaphor for the chocking control Philip has over his wife. The necklace is a collar of dull silver which rises up almost to her chin. That is way she can hardly move her head, she hardly eats - a state of passivity. And the collar is primitive and barbaric. As if she is like a mastiff bitch wearing a chocking collar. Moreover Margaret's dumbness can be seen as a literary transformation into a passive voiceless-being. Melanie and Margaret lose their identity and personality - their empowerments when they are forced to wear old fashioned cheap dresses which do not satisfy their joys and desires. Further, Melanie tries certain representations of feminity without questioning the rightness. The traditional role models prescribed for the female gender is subconsciously accepted by the two submissive women characters [5].

Now we shall critically analyse the second type of feminity - "feminity as self-invention and role mobilization". It is a deliberate negation to the 'entrapment' type of female characters. Actually through the second type of feminity, Carter is trying to come to centre of critical discussion, to explore the feminity and to subvert the gender hierarchy. In Paulina Palmer's word this second type of feminity is fabricated by "a strong degree of agency and self-determination". It conveys Carter's idea of negating the traditional prescribed scripts to the feminity. Carter's "New Woman" is Fevvers in 'Nights at the Circus'. The hint of female empowerment is perceived through her size and strength: 
"God! She could easily crush him to death in her huge arms, although he was a big man with the strength of Californian sunshine distilled in his limbs". [6]

She is six feet two in her stockings. It means Fevvers takes the spaces in literal and in figurative meaning. It is not only her size that gives her a special space in the patriarchal society, but also most bizarre aspect - the wings. These are seen as the metaphor of 'freedom'. Half bird, half woman, Fevvers can be seen as an 'other', as 'unknown' who does not obey the gender hierarchy. She is the personification of Carter's feminist view. A sense of 'carnivalesque' is hinted through the description of her face. Her face seems to be "painted up by those artists who build carnival ladies" [7]. These descriptions of Fevvers do not fit to the traditional description of feminity - beautiful, tender, well-proportioned and angel-like. All the descriptions assigned to Fevvers give the hints of male behaviour. She is confident that she can transform the way a man and a woman live and behave with each other:

"I'll make him into the New Man, in fact, fitting mate for the New Woman, and onward we'll march hand in hand into the New Century" [8]

Fevvers dreams that she will marry Walser and will want equal right. She will not be the downtrodden one like that of the traditional girl. She dreams of women who will get wings like her. She will show them the way to freedom which is not gained in the doll's house. She will sing with them for the new world - the 'good morrow' [9].

Now we will settle our discussion on the instances of transformation from the first type of feminity to the second type. This movement hints the transformation of woman from the traditional concept of feminity and the idea how the women should see themselves. In Carter's short story 'The Lady of the House of Love' from "The Bloody Chamber", she raises a question: "Can a bird only sing the song it knows or can it learn a new song?" [10] which denies the previous script written by the patriarchal society for the women. In this short story the protagonist is a bloodthirsty vampire who devours her victims. But she is also a puppet as she is controlled by the bloody expectations of her "atrocious ancestors" [11]:

"For she seemed inadequately powered by some slow energy of which she was not in control" [12]

But when she meets with the fearless and unprejudiced young soldiers, she wants to be a human. The young soldier accepts her as she is not how others would want her to appear. And she decides to let him live at the cost of her own life. Through her death she finally revolts against her ancestors.

"In death, she looked far older, less beautiful and so, for

the first time, fully human" [13]

Though she cannot enjoy her freedom for her death, she transforms herself from the puppet to a "New Woman".

In her short story 'The Tiger's Bride', also included in her collection "The Bloody Chamber", Carter through the representation of the female protagonist, hints the transformation from the first type to the second. Here the female protagonist is a puppet in her father's hand. In a game of cards her father loses her two an unknown mysterious character called "The Beast" who is actually a tiger wearing a mask with a human face. Now the beast only wish is to see the young girl naked. When the girl refuses, as a punishment she has to see the beast in nakedness. But it has a positive effect as for the first time for the beast's openness, she have the taste of freedom:

"I felt I was at liberty for the first time in my life." [14]

Later in the story, she willingly visits the beast and becomes naked. When the beast licks her skin, she feels the renewal of life. She is now able to recognize her sexual needs and desires and of course her true identity. She ultimately transforms into a tigress to match with the tiger and draws a sound revolution against the domination imposed on her in particular and on the female gender in general.

Another female character which not as surprising as the previous characters bears the testimony of the transformation from the first type of feminity to second type is Mignon in 'Nights at the Circus' who is violently dominated by her husband, the Ape-Man. He marries her only to sexually assault her. No sooner the marriage completes, than the conjugal relationship walks in its routine life -

"On the third day on the road, he beat her because she burned the cutlets. [...] On the fourth day, he beat her because she forgot to empty the chamber-pot [...]. On the fifth day, he beat her because he had formed the habit of beating her." [15] 
When the Ape-Man finds that she have had sex with the Strong Man, he beats her violently and throws her on to the Russian street as half naked. Later she is rescued by Fevvers and Walser and helped to get a role in the performance of the Princess of Abyssinia. Finding new happiness with the Princess of Abyssinia, Mignon freely satisfies her sexual desires, becomes self-confident and self-determined.

In 'The Loves of Lady Purple' from "Fireworks", Lady Purple stands as the vivid presentation of feminity which transforms from the submissive type to the revolutionary. She is the heroine of Asiatic Professor's puppet performance and is literary controlled by him. She is an orphan, a prostitute and murderer of her foster parents. As the years have gone by she has grown evermore frail. One day she dies and the God transforms her into a wooden effigy. The puppeteer finds the wooden effigy and takes it for puppet show. One day, the puppeteer, in his lodging, is working on the repair of the wooden effigy, and to his surprise the effigy becomes real, feeding on his blood and burning the body she leaves to find a brothel, for she can only be what he has made her - a puppet who performs the role of female fatale, a prostitute [16]. Here the dominated puppet transformed into life. It is a transformation from puppet to woman. Lady Purple wakens from the sleeping wood and shows its empowerment.

Now I am going to explore the character which is from the beginning a self-determined character and which successfully and confidently turns to be a "New Woman". She is the protagonist of Carter's short story 'The Company of Wolves' from the collection 'The Bloody Chamber'. She is strong-minded and does not fear of wild beast. One day, on her way to her grandmother she meets a young handsome boy. They make a bet on who will arrive first. To her surprise, having arriving first, the boy transforms into a wolf. The girl becomes scared but wins her fear by her strong resolution. She takes off her dress and also prompts the wolf to undress. She gives kisses him.

"The girl burst out laughing; she knew she was nobody's meat." [17]

The girl takes control over the situation only through her free will. Her laughing and extreme sexuality decreases the fearful thought. She embodies the female empowerment while entering into the natural sexual performances and ends up as a loving and affectionate couple. Merja Makinen exclaims that the wolf can be seen as projection of a "feminine libido", as a "forbidden" sensuality. Here for her self-assured and self-invented characteristic, the girl remains as a "New woman" [18].

Through the suitable medium of Gothic, Angela Carter is successful to draw the qualities to excesses and transgressions only to attract our attentions to contemporary problems which her feminist self has seen. The first types of women cannot take their own decisions and wait for the society to take decisions for them. They are not able to think that there are lots of opportunities to change their lives. But the second types of women take their own decisions and lead their own lives of erotic desires. Thus, where first type of feminity arises 'fear' in our mind, second type of feminity shows the glimpse of 'hope'. In classical Gothic fictions, mostly the writers remain entrapped by the social values of the patriarchal society though they announce their voice for the rights of women in the society. But here Carter is quite different from them in her attitude of producing the 'entrapment' type of women to grotesqueness to receive our critical insights, and further producing women characters who are self-determined and self-invented to teach the lesson of how women should see themselves, and ultimately showing the transformation a woman takes to be a better woman - a "New Woman" [19].

\section{References}

[1]. Paulina Palmer, 'Gender as Performance in the Fiction of Angela Carter and Margaret Atwood' in Joseph Bristow and Trev Broughton, eds., 'The Infernal Desires of Angela Carter' (Longman, 1997)

[2]. Angela Carter, 'Nights at the Circus', (London: Vintage, 1984, p70)

[3]. Angela Carter, 'The Magic Toyshop', (London: Virago, 1967, p102-103)

[4]. Angela Carter, 'The Magic Toyshop', (London: Virago, 1967, p186-187)

[5]. Angela Carter, 'The Magic Toyshop', (London: Virago, 1967, p126-127)

[6]. Angela Carter, 'Nights at the Circus', (London: Vintage, 1984, p57)

[7]. Angela Carter, 'Nights at the Circus', (London: Vintage, 1984, p37)

[8]. Angela Carter, 'Nights at the Circus', (London: Vintage, 1984, p334)

[9]. Angela Carter, 'Nights at the Circus', (London: Vintage, 1984, p338-339)

[10]. Angela Carter, 'The Bloody Chamber', (London: Vintage, 1979, p108)

[11]. Angela Carter, 'The Bloody Chamber', (London: Vintage, 1979, p107)

[12]. Angela Carter, 'The Bloody Chamber', (London: Vintage, 1979, p118)

[13]. Angela Carter, 'The Bloody Chamber', (London: Vintage, 1979, p124)

[14]. Angela Carter, 'The Bloody Chamber', (London: Vintage, 1979, p72)

[15]. Angela Carter, 'Nights at the Circus', (London: Vintage, 1984, p164)

[16]. http://en.wikipedia.org/wiki/The_Bloody_Chamber

[17]. Angela Carter, 'The Bloody Chamber', (London: Vintage, 1979, p138)

[18]. Merja Makinen, 'Angela Carter's The Bloody Chamber and the Decolonisation of Feminine Sexuality' in Alison Easton, eds., 'Angela Carter', (Basingstoke and London: Macmillan.20-36)

[19]. Prof. Dr. Greta Olson, 'Representation(s) of Feminity in Angela Carter's Postmodern Female Gothic', http://fss.plone.unigiessen.de/fss/faculties/f05/engl/ginf/downloads/stylesheets/ba-thesis-exemplary/file/Olson Thesis.pdf 